\title{
PATHOGENETIC ROLE OF MACROPHAGE COLONY-STIMULATING FACTOR (CSF-1) IN PREDICTING ENDOMETRIOID DISEASE
}

DOI: 10.36740/WLek202108128

\author{
Yuliia A. Orlova, Antonina M. Hromova, Igor P. Kaidashev, Oksana A. Shlykova, Olha V. Izmailova, Vitaliiy B. Martynenko
}

POLTAVA STATE MEDICAL UNIVERSITY, POLTAVA, UKRAINE

\begin{abstract}
The aim: To assess the CSF - 1 level in peritoneal fluid and menstrual blood of women with endometrioid disease and to investigate its diagnostic and prognostic specificity. Materials and methods: The study included 80 women of child-bearing age (mean age $30.95 \pm 6.49$ years) with benign gynaecological pathology of the ovaries and / or fallopian tubes. The women included in the study were divided into two groups: study group ( $n=50$, mean age $31.04 \pm 6.3$ years), consisting of patients with confirmed endometrioid disease, and control group ( $n=30$, mean age $30.8 \pm 6.8$ years), involving individuals without signs of endometriosis ( $p>0.05)$.

Results: We have found significantly higher level of CSF-1 content in the peritoneal fluid in the subjects of the study group (2027.05 $\pm 732.64 \mathrm{pg} / \mathrm{ml}$ ) compared with those in the control group $(1725.62 \pm 466.06 \mathrm{pg} / \mathrm{ml})(\mathrm{p}=0.029)$. There is a tendency towards an increase in CSF- 1 level in women with endometriosis in its more severe stages and more severe and extended adhesions. The investigation of CSF- 1 content in menstrual blood has demonstrated significant increase in its values in the women of the study group $(9431.6 \pm 2866.22 \mathrm{pg} / \mathrm{ml})$ compared with the values in the control group $(6637.12 \pm 954.05 \mathrm{pg} / \mathrm{ml}),(\mathrm{p}=0.00004)$. Thus, there is a tendency towards the growth in CSF-1 level in peritoneal fluid and menstrual blood in women with endometriosis and concurrent increase in severity of the disease.

Conclusions: There has been found significant increase in CSF-1 content in women with endometrioid disease in both peritoneal fluid and menstrual blood (1.2 and 1.4 times, respectively). Thus, macrophage growth factor (CSF-1) can be used as a diagnostic and prognostic criterion in evaluating the progression of endomertioid disease.
\end{abstract}

KEY WORDS: endometriosis, peritoneal fluid, menstrual blood

Wiad Lek. 2021;74(8):1939-1944

\section{INTRODUCTION}

Over the recent period, endometriosis has become the subject of very close and urgent attention for medical researchers and clinicians. Nowadays, according to the WHO report, the prevalence of this disease reaches $10 \%$, moreover, there is a tendency to its growth [1]. What is particularly noteworthy is the fact that the diagnosis of endometriosis ranges from $10 \%$ to $70 \%$ in child-bearing women according to the reports of authors [2,3].

The ability of endometrium-like tissues to be misplaced throughout the body that is also known as endometrioid heterotopias, including spread to adjacent organs and tissues, as well as to individual systems of the macroorganism allows us to consider this problem not as a local body reaction, but as endometrial disease (ED) [4].

In the modern scientific literature, there have been many theories of endometriosis clarifying the aetiology of endometriosis, but none of them are in the framework of a single and ultimate pathogenetic picture. This can be explained by the variety and complexity of the mechanisms involved in the formation of endometrioid disease. The long list of the theories of the origin go endometriosis includes coelomic, implantation, genetic, hormonal, inflammatory theories $[5,6]$.

The implantation theory is known as one of the leading theories explaining the development of endometriosis.
According to this theory, endometriosis may occur due to the retrograde reflux of menstrual blood through the cervical canal and fallopian tubes into the abdominal cavity, resulting in the adhesion and subsequent invasion of viable endometrial cells into various structures of the abdominal cavity [7].

The penetration of endometrial cells into the abdominal cavity is accompanied by the development of inflammatory reactions within the cavity. The inflammation can be explained by the presence of macrophages, which have entered there retrogradely and then migrate to the foci of endometrial tissue [8]. Peritoneal fluid normally contains macrophages, but in endometrioid disease there is a predominance of macrophages of the second type (M2) [9].

One of the factors involved in the processes of differentiation, proliferation and growth of macrophages, is macrophage growth factor - 1 (CSF - 1), which is mainly produced by macrophages, but an increase in CSF-1 and its receptors are also observed in the co-culture of endometrial cells of women with endometriosis and peritoneal mesothelial cells. Thus, the endometrium itself can act as a CSF - 1 producer [10].

Though there are various data regarding the CSF- 1 content in the peritoneal fluid in women with endometriosis, most scientific studies point out the association between the CSF -1 growth and the progression of endometriosis. 
By binding to its receptor, CSF -1 induces the attraction, growth, and differentiation of macrophages [10], and in particularly, M2 type [11]. CSF - 1 may also be involved in the early stages of endometriosis [12].

Given the multi-componential pathogenesis in terms of endometrioid disease, its diagnosis is often challenging, especially when using non-invasive techniques. The gold standard commonly accepted in the diagnosis of this disease today is laparoscopic examination with mandatory histological investigation [13].

Though laparoscopy enables to perform surgical treatment of the disease, and when using chromohydrotubation, to check the patency of the fallopian tubes simultaneously $[14,15]$, this approach can not help to detect the intensity and depth of entometrium tissues invasion [15].

Non-invasive diagnostic methods now available do not provide exact and specific information as well, but there are many reports emphasizing the diagnostic role of pathogenetic markers of endometrioid disease [14-16]. Therefore, the search for new diagnostic options to identify the intensity and extent of endometrial disease is one of ambitious tasks set by the medical research community.

\section{THE AIM}

The purpose of the study is to assess the CSF - 1 content in peritoneal fluid and menstrual blood in women with endometrioid disease and to investigate its diagnostic and prognostic specificity.

\section{MATERIALS AND METHODS}

The study included 80 women of child-bearing age (mean age $30.95 \pm 6.49$ years) with benign gynaecological pathology of the ovaries and / or fallopian tubes, who were operated on at the gynecological departments of medical and healthcare settings of Poltava: 5th Municipal Clinical Hospital, Poltava Central District Clinical Hospital, and Poltava Municipal Clinical Maternity Hospital.

The women included in the study were divided into two groups: study group ( $\mathrm{n}=50$, mean age $31.04 \pm 6.3$ years), consisting of patients with confirmed endometrioid disease, and control group ( $\mathrm{n}=30$, mean age $30.8 \pm 6.8$ years), including individuals without signs of endometriosis ( $\mathrm{p}>0.05)$.

Endometrioid disease was diagnosed based on the criteria of the current Order of the Ministry of Health of Ukraine № 319, April, 6, 2016, “Unified clinical protocol of primary, secondary (specialized) and tertiary (high level of specialty care) medical care "Tactics of managing patients with genital endometriosis" [14].

Inclusion criteria in the study: child-bearing age, endometrioid heterotopia of different localization confirmed by ultrasound and clinical manifestations with subsequent laparoscopic imaging, benign diseases of the ovaries and fallopian tubes, infertility of unknown aetiology (primary and secondary).

Exclusion criteria: ectopic pregnancy, malignant neoplasms of the reproductive organs, missing uterus or abnormalities of uterine development.

Having obtained informed consent from the patients for diagnosis and treatment (including surgical operation), we collected the menstrual blood from the women of the both groups by using menstrual cups on the $2^{\text {nd }}-3^{\text {rd }}$ days of the menstrual cycle before the surgical treatment.

Laparoscopy was performed on a laparoscopic stand ("Contact", Ukraine) with a video block Endo-Digi-View 3 CCD ("WISAP Medical Technology", Germany). During laparoscopy or laparotomy procedures, approximately $5-15 \mathrm{ml}$ of peritoneal fluid was taken using a sterile catheter and syringe and put into sterile vacuum test tubes 16 ("Vacumed", Italy) for following enzyme-linked immunosorbent assay.

Assessment concentration of CSF-1 in peritoneal fluid and menstrual blood was performed at the Research Institute of Genetic and Immunological Foundations of Pathology and Pharmacogenetics, Poltava State Medical University.

To assess the concentration of CSF-1, sterile vacuum test tubes 16 ("Vacumed", Italy) with peritoneal fluid and menstrual blood were placed in a Thermo Scientific Medifuge centrifuge (Germany) and centrifuged at $1000 \mathrm{rpm}$ for 20 minutes, then the supernatant, approximately $3.5 \mathrm{ml}$ was taken by a Pasteur pipette and placed into eppendorf tubes. Enzyme-linked immunosorbent assay was performed using Human MCSF set of reagents (Macrophage Colony Stimulating Factor 1) ELISA Kit (Elabscience, USA) on a microplate photometer for enzyme-linked immunosorbent assay:LabLine-026 (LABLINE*, Austria).

The findings obtained were calculated in $\mathrm{pg} / \mathrm{ml}$. The study design was approved by the Commission on Bioethics, Poltava State Medical University (Minutes № 174, May, 28,2019).

Statistical data processing was performed using MedStat (S/N MS00019) and Statistica 10. We applied descriptive statistics methods. To determine the difference between the studied indicators, both parametric and non-parametric methods were used: between quantitative indicators- the Student's t-test or Mann-Whitney U-test after testing the distribution for normality; Fisher's exact test and the $\chi^{2}$ test Pearson were applied to compare qualitative indicators. Quantitative indicators in the studied groups are represented as average sample values (M) and their standard deviation (SD). Qualitative indicators are given as frequencies and their percentages ratio. The difference value of $\mathrm{p}<0.05$ was considered statistically significant.

\section{RESULTS}

Among the 50 women of the study group, 20 women (40\%) were diagnosed as having endometrioid disease, and $30(60 \%)$ women had endometrioid disease and infertility. Among the 30 women of the control group, 17 (56.7\%) individuals had benign ovarian tumours, $10(33.3 \%)$ women had infertility of unknown origin, and $3(10 \%)$ women had hydrosalpinx.

Prior to the surgical operation, at the pre-hospital stage, according to the Order of the Ministry of Health of Ukraine 
Table I. The comparison of CSF-1 content in peritoneal fluid depending on the severity of adhesion process in endometrioid disease. Difference is statistically significant at $p<0.05$ using Student's t-test.

\begin{tabular}{cccc}
\hline $\begin{array}{c}\text { Degrees of severity of } \\
\text { adhesion process }\end{array}$ & $\mathbf{2}$ & $\mathbf{3}$ & $\mathbf{4}$ \\
\hline 1 & 0,07 & $0,02^{*}$ & $0,013^{*}$ \\
\hline 2 & & 0,76 & 0,3 \\
\hline 3 & & & 0,32 \\
\hline
\end{tabular}

№ 417, July 15, 2011 "On the organization of outpatient obstetric and gynaecological care in Ukraine", the women of both groups underwent pelvic ultrasound scanning [17].

$44(88 \%)$ women of the study group and $29(96.7 \%)$ women of the control group underwent pelvic ultrasound examination. In the group of women with endometrioid disease who underwent pelvic ultrasound scan $(\mathrm{n}=44=$ $100 \%$ ), endometriosis was found in 29 women that made up $65.9 \%$. Thus, our study has demonstrated that ultrasound scan is far from being an exceptionally specific technique of detecting endometrioid disease.

Subsequently, to exclude cancerous diseases, Cancer antigen 125 (CA-125) and Human epididymis protein 4(HE 4) markers were determined in both groups of the subjects. These markers are considered as non-specific for endometriosis, but their assessment can be recommended when ovarian malignancies are suspected [18].

The average value of CA 125 in the study group was $48.62 \pm 40.45 \mathrm{U} / \mathrm{ml}$ (a normal value is $35 \mathrm{U} / \mathrm{ml}$ ) and was statistically different from the values in the control group that was $19.26 \pm 12.66 \mathrm{U} / \mathrm{ml}$ (U criterion by Mann-Whitney U-test equalled 106.0, $\mathrm{p}=0.003)$. However, the CA 125 level, which exceeded normal values in the group of women with endometriosis, was found only in $48.14 \%$ of the women with endometrioid disease, thus, we can suggest this non-invasive method is not highly specific for diagnosis of endometrioid disease.

The average value of HE 4 was $50.56 \pm 28.89 \mathrm{pmol} / \mathrm{l}$ in the study group, and $51.68 \pm 10.87 \mathrm{pmol} / \mathrm{l}$ in the control group that was not statistically different $(p>0.05)$, and did not exceed the age norm $(60.5 \mathrm{pmol} / \mathrm{l})$. That is, the values of this indicator were not indicative in both groups.

During laparoscopy or laparotomy interventions, we checked for the severity of the adhesion process, the presence or absence of endometrioid heterotopias, ovarian and / or fallopian tube lesions in the subjects of both groups.

The severity and extent of adhesion process were assessed according to the classification of adnexal adhesions of the American Fertility Society (ASRM)[19] and then scored. There are four degrees: minimal (I degree) $-0-5$ scores, mild (II degree) - 6 - 10 scores; moderate (III degree) - $11-20$ scores and severe (IV degree) - over 21 [20]. The severity of endometriosis was evaluated according to the criteria of current Order of the Ministry of Health of Ukraine № 319, April, 6, 2016, “Unified clinical protocol of primary, secondary (specialized) and tertiary (high level of specialty care) medical care "Tactics of managing patients with genital endometriosis". Based on this, there are four stages of the disease: I stage ( 1 - 5 scores), II stage (6 - 15 scores), III stage (16 - 40 scores), IV stage (40 scores and more).

Among the women with endometrioid disease, the adhesion process of varying severity was diagnosed in 42 $(84 \%)$ individuals. The severity and extent of the adhesion process in the pelvic area in the study group were classified as follows: mild adhesion (I degree) was found in $12(24 \%)$ women; the same number of the participants, 12 (24\%), had moderate adhesion (II degree); the severe adhesion (III degree) was found in 10 (20\%) women, and 8 (16\%) women had extremely intensive and extended adhesions.

14 (46.7\%) women of the control group were diagnosed as having adhesions $(\mathrm{p}<0.001)$; the severity and extent of adhesion were significantly lower compared with the study group. Mild adhesions (I degree) were found in 8 (26.7\%) women, and moderate adhesions (II degree) were diagnosed in $6(20 \%)$ women. There was also a significant difference between the women with severe and extremely severe adhesions in the study and control groups; the women of the study group were diagnosed as more often having adhesions of III and IV severity degrees compared with the control group $(\mathrm{p}<0.05)$.

When assessing the extent and depth of endometrioid disease among the women of study group, we classified those parameters into one of four stages (I - minimal, II mild, III - moderate, and IV - severe). We revealed that I stage of endometrioid disease was found in 2 (4\%) women; surprisingly, but no cases in mild stage were detected at all; the largest share of 33 (66\%) women was diagnosed as having moderate stage of the disease, the IV stage was found in 15 (30\%) women.

The evaluation of CSF-1 content in peritoneal fluid in 49 women of the study group and 30 women of the control group demonstrated a significant difference. The average value of CSF-1 content in the study group was $2027.05 \pm$ $732.64 \mathrm{pg} / \mathrm{ml}$ that statistically differed from the values of CSF-1 content in the control group, $1725.62 \pm 466.06 \mathrm{pg} /$ $\mathrm{ml}$ (Mann-Whitney U- test $-519.5, \mathrm{p}=0.029)$.

CSF-1 content in peritoneal fluid was also evaluated taking into account the severity of the adhesion process in both groups. The average value of CSF- 1 content in the women of the study group with mild adhesion (I degree) was $1554.66 \pm$ $666.68 \mathrm{pg} / \mathrm{ml}$; the average value of CSF-1 content in the women with moderate adhesions (II degree) was $2098.73 \pm$ $740.4 \mathrm{pg} / \mathrm{ml}$; in the cases of severe adhesions (III degree) the value of CSF- 1 content was $2179.97 \pm 453.76 \mathrm{pg} / \mathrm{ml}$, and in the cases of the extremely severe adhesions (IV degree) it was $2470.26 \pm 735.41 \mathrm{pg} / \mathrm{ml}$. When comparing the severity of the adhesion process in endometrioid disease, statistical difference was found between I and III degrees of severity, and between I and IV degrees of the severity, $p=0.02$, and $\mathrm{p}=0.013$, respectively. There is a tendency towards the CSF - 1 content growth concurrent to the increase in the severity of the adhesion process (Table I).

The results obtained by the assessment of CSF- 1 content in the peritoneal fluid in the control group depending on 
the severity of the adhesion process demonstrate that under the condition of I degree, the average CSF- 1 content was $1813.98 \pm 247.4 \mathrm{pg} / \mathrm{ml}$; under the II degree, it was $1424.99 \pm$ $339.97 \mathrm{pg} / \mathrm{ml}$. Statistically significant differences were observed between the women with I and II degrees of adhesion severity, and in the women with the II degree, the indicator was 1.3 times lower (Mann-Whitney U- test-8, $p=0.045$ ). In contrast to the group with endometrioid disease, the control group showed a tendency towards the decrease in the values of CSF-1 level depending on the severity of adhesions.

Thus, we can asset that in endometrioid disease, CSF-1 in the peritoneal fluid not only contributes to its development, but also promotes the formation of more severe and extended adhesion process in the pelvic area.

The evaluation of CSF-1 level in peritoneal fluid of the women with endometrioid disease depending on its severity demonstrated that in endometriosis of I degree $(n=2)$, the average CSF-1 content was $1409.3 \pm 857.16 \mathrm{pg} / \mathrm{ml}$, in endometriosis of III degree $(\mathrm{n}=33)$, the average CSF-1 content was $1973.41 \pm 706.37 \mathrm{pg} / \mathrm{ml}$, and in endometriosis of IV degree $(\mathrm{n}=14)$, the average CSF-1 content was $2241.72 \pm 762.57 \mathrm{pg} / \mathrm{ml}$, i.e. there was a tendency to the cytokine growth in more severe stages of the disease.

Before the surgical operation, we investigated CSF-1 content in menstrual blood of 43 women of the study group and 19 women of the control group. The investigation showed significant differences between the women of these two groups: CSF-1 content in the study group was $9431.6 \pm$ $2866.22 \mathrm{pg} / \mathrm{ml}$, and $6637.12 \pm 954.05 \mathrm{pg} / \mathrm{ml}$ in the control group (Mann-Whitney $\mathrm{U}$ - test $-140, \mathrm{p}=0.00004$ ). No statistically significant differences in CSF-1 content in the menstrual blood were found in the women in terms of the severity of endometrial disease, the only peculiarity was the CSF-1 growth during the transition from the III to IV degree of severity of the disease: CSF- 1 content in III degree of endometrioid disease was $9120.21 \pm 2939.01 \mathrm{pg} /$ $\mathrm{ml}$, while in the IV degrees, it reached 10039.16 \pm 2611.03 $\mathrm{pg} / \mathrm{ml}$.

\section{DISCUSSION}

Today, endometriosis is ranking the $3^{\text {rd }}$ position among gynaecological diseases in women who seek medical attention [13]. Diagnostic options, especially non-invasive, fail to diagnose the disease at the stage of outpatient treatment. It should be stressed that special attention should be paid to young people who develop this disease from adolescence as this cohort of population poses some challenges in both early diagnosis and early treatment.

Although, according to the relevant literature, the sensitivity and specificity of pelvic ultrasound scanning in detecting endometriosis reaches $85 \%$ [21], currently, ultrasound scanning technique is considered as a quite effective diagnostic tool. Moreover, complexity in diagnosis of endometriosis is also associated with its ability to mimic some other diseases of the pelvic organs that impedes making a correct final diagnosis [22]. Based on our findings, only
$65.9 \%$ of endometriosis cases were detected by ultrasound scanning at the stage of outpatient treatment.

The latest guidelines do not insist on routine use of CA-125 and HE 4 markers assessment because of their discussible reliability in the detection of endometrial disease [14-16], but, nevertheless, these techniques are also used in medical practice. The results of our study support the existing data [14-16] regarding the low diagnostic value of these markers. Though the differences in the study group and control group are significant $(48.62 \pm 40.45 \mathrm{IU} / \mathrm{ml}$ vs. $19.26 \pm 12.66 \mathrm{IU} /$ $\mathrm{ml}$, respectively), they exceed the age norm by $48.14 \%$, therefore these markers are not reliable neither in the preliminary diagnosis nor in the differential diagnosis of endometriosis. That is, without performing invasive intervention and histological verification, which are still considered as the gold standard in the diagnosis of endometrioid disease, making diagnosis of this pathology seems still not possible now. This induces medical researchers and clinicians to look for new non-invasive diagnostic methods.

Two theories lie at the basis of out study. First, in retrograde menstruation, when blood flows back, endometrial cells enter the abdominal cavity, stick to the pelvic walls and surfaces of pelvic organs, and continue growing (implantation theory), but retrograde blood flow is observed in $90 \%$ of healthy women. Then, following endometrial cells, macrophages migrate into the peritoneal fluid, causing an aseptic inflammatory process. The CSF-1 level, which is associated with type 2 macrophages [23] having pro-oncogenic, proangiogenic, regenerative functions and thus protecting endometrioid heterotopias from being destroyed by macroorganisms [24], can vary in endometriosis in peritoneal fluid according to reports of different authors $[10,25]$. Our study shows a significant prevalence of this factor, in 1.2 times, in the peritoneal fluid in the study group over the control group. The tendency of CSF-1 level to increase with the progression of endometrioid disease can influence the progression of adhesions in pelvic area.

In menstrual blood, given that the endometrium itself is the producer of this factor [10], we also have found significant differences, in 1.4 times, between the study and control groups. That is, this factor when entering the peritoneal fluid with retrograde blood flow creates favourable conditions for the development of endometrioid disease and promotes its progression. We have also revealed a tendency towards an increase in CSF-1 content in both menstrual blood and peritoneal fluid depending on the stage of endometrial disease.

\section{CONCLUSIONS}

Out study has demonstrated significant increase in CSF1 content in women with endometrioid disease in both peritoneal fluid and menstrual blood (1.2 and 1.4 times, respectively). Thus, macrophage growth factor (CSF-1) can serve as a diagnostic and prognostic criterion in evaluating the progression of endomertioid disease.

Moreover, the results obtained point out diagnostic appropriateness of determining macrophage growth factor, 
both in the pre-hospital stage in menstrual blood and during laparoscopic or laparotomy intervention in the diagnosis of endometrioid disease and determining its severity. Assessment of CSF-1 content in menstrual blood can be applied in adolescents, who have clinical manifestations of endometriosis, in order to manage and control the disease before histological verification (when necessary).

\section{REFERENCES}

1. Zondervan K.T., Becker C.M., Missmer S.A. Endometriosis. N Engl J Med. 2020 Mar 26;382(13):1244-1256. doi: 10.1056/NEJMra1810764.

2. Pshenichnyuk E.Yu., Asaturova A.V., Adamyan L.V. et al Immunogistokhimicheskyie osobennosti eutopicheskogo i ektopicheskogo endometriya u patsientok $s$ retsidiviruyushchim techeniem endometrioidnykh kist yaichnikov[Immunohistochemical features of eutopic and ectopic endometrium in patients with a recurrent course of endometrioid ovarian cysts]. Akusherstvo i ginekologiya. 2018; 3:84-95. doi: 10.18565/aig.2018.3.84-95.(in Russian).

3. Veropotvelyan P.N., Guzhevskaya I.V., Veropotvelyan N.P. Endometrioz u patsientok sotsrochennoy beremennost'yu, stradayushchikh besplodiem [Endometriosis in patients with a deferred pregnancy who suffer from sterility]. Zdorov'ye zhenshchiny. 2012; 5(71):155-159.(in Russian).

4. Baranov V.S. Endometrioz kak problema sistemnoj genetiki [Endometriosis as a problem of systemic genetics]. Zhurnal akusherstva i zhenskih boleznej. 2013; 62(1):71-78. ( in Russian).

5. Wang Y., Nicholes K., Shih I.M. The Origin and Pathogenesis of Endometriosis. Annu Rev Pathol. 2020;15:71-95. doi: 10.1146/annurevpathmechdis-012419-032654.

6. Rolla E. Endometriosis: advances and controversies in classification, pathogenesis, diagnosis, and treatment. F1000Res. 2019;8:F1000. doi: 10.12688/f1000research.14817.1.

7. Kononov A.V., Mozgovoy S.I., Mozgovaya E.I. et al. Endometrioz:teorii proiskhozhdeniya [Endometriosis: theories of origin]. Omskij nauchnyj vestnik. 2008; 1(65):32-36. (in Russian).

8. Sokolov D.I, Kondrat'yeva P.G, Yarmolinskaya M.I. etal.Soderzhaniekhemokinov i tsitokinov v peritoneal'noy zhidkosti bol'nykh naruzhnym genital'nym endometriozom razlichnoy stepeni tyazhesti. [Contents of chemokines and cytokines in peritoneal fluid from the patients with endometriosis of various severity]. Meditsinskaya Immunologiya. 2007; 9(1):85-90. (in Russian).

9. Hudson Q.J., Ashjaei K., Perricos A. et al. Endometriosis Patients Show an Increased M2 Response in the Peritoneal CD14+low/ CD68+low Macrophage Subpopulation Coupled with an Increase in the T-helper 2 and T-regulatory Cells. Reprod Sci. 2020;27(10):1920-1931. doi: 10.1007/s43032-020-00211-9.

10. Budrys N.M., Nair H.B., LiuY.G. et al. Increased expression of macrophage colony-stimulating factor and its receptor in patients with endometriosis. FertilSteril.2012;97(5):1129-35.e1. doi:10.1016/j.fertnstert.2012.02.007.

11. Hogg C., Horne A.W., Greaves E. Endometriosis-Associated Macrophages: Origin, Phenotype, and Function. Front Endocrinol (Lausanne). 2020;11:7. doi: 10.3389/fend0.2020.00007.

12. Aligeti S., Kirma N.B., Binkley P.A. et al. Colony-stimulating factor-1 exerts direct effects on the proliferation and invasiveness of endometrial epithelial cells. Fertil Steril. 2011;95(8):2464-6. doi: 10.1016/j. fertnstert.2011.03.026.

13. Zaporozhan V.M., Tatarchuk T.F., Kaminskyi V.V. et. al. Natsionalnyi konsensus shchodo vedennia patsiientok iz endometriozom [National consensus on the management of patients with endometriosis]. Reproduktyvna endokrynolohiia. 2015;4(24):7-12. doi: 10.18370/2309-
4117.2015.24.7-12 (in Ukrainian).

14. Nakaz MOZ Ukrainy № 319 vid 6.04.2016. «Unifikovanyi klinichnyi protokol pervynnoi, vtorynnoi (spetsializovanoi) ta tretynnoi (vysokospetsializovanoi) medychnoi dopomohy «Taktyka vedennia patsiientok z henitalnym endometriozom». ["Unified clinical protocol of primary, secondary (specialized) and tertiary (high level of specialty care) medical care"Tactics of managing patients with genital endometriosis"]. (in Ukrainian).

15. Novikova E.I., Barinov S.V., Mozgovoy S.I. et al. Novye podkhody k diagnostike genital'nogo endometrioza [New approaches to the diagnosis of genital endometriosis]. Omskiy nauchnyy vestnik. 2012; 1(108):46-48. (in Russian).

16. Hwang H., Chung Y.J., Lee S.R. et al. Clinical evaluation and management of endometriosis: guideline for Korean patients from Korean Society of Endometriosis. Obstet Gynecol Sci. 2018;61(5):553-564. doi: 10.5468/ ogs.2018.61.5.553.

17. Nakaz MOZ Ukrainy № 417 vid 15.07.2011 «Pro orhanizatsii ambulatornoi akushersko-hinekolohichnoi dopomoho v Ukraini»["On the organization of outpatient obstetric and gynaecological care in Ukraine"].(in Ukrainian).

18. Ulrich U., Buchweitz 0., Greb R. at al. National German Guideline (S2K). Guideline for Diagnosis and Treatment of Endometriosis, AWMF Registry No 015-045. Geburtsh Frauenheilk. 2014; 74:1104-1118. doi:10.1055/s-0034-1383187.

19. The American Fertility Society classifications of adnexal adhesions, distal tubal occlusion, tubal occlusion secondary to tubal ligation, tubal pregnancies, müllerian anomalies and intrauterine adhesions. Fertil Steril. 1988;49(6):944-55. doi: 10.1016/s0015-0282(16)59942-7.

20. Zaharov I.S., Ushakova G,A., Dem'janova T.N. et al. Spaechnaja bolezn' organov malogo taza: sovremennye vozmozhnosti profilaktiki [Adhesive disease of the pelvic organs:modern prevention opportunities]. Consilium Medicum.2016;18(6):71-73. doi:10.26442/2075-1753_2016.6.71-73. (in Russian).

21. Yarmolinskaya M.I., Rusina E.I., Khachaturyan A.R. et al. Klinika i diagnostika genital'nogo endometrioza [Clinical picture and diagnosis of genital endometriosis]. Zhurnal akusherstva i zhenskih boleznej. 2016; 65 (5):4-21. doi: 10.17816/JOWD6554-21. (in Russian).

22. Padrul' M.M, Shirokina EV. Makhmudova SE. Problema diagnostiki endometrioza vramkakh sistemnogo zabolevaniya [Problem endometriosis diagnosis within framework of systemic disease]. Permskiy meditsinskiy zhurnal. 2018; 35(1):21-26. doi:10.17816/pmj35121-26. (in Russian).

23. Jones C.V., Ricardo S.D. Macrophages and (SF-1: implications for development and beyond. Organogenesis. 2013;9(4):249-60. doi: 10.4161/org.25676.

24. Lin Y.H., Chen Y.H., Chang H.Y. et al. Chronic Niche Inflammation in Endometriosis-Associated Infertility: Current Understanding and Future Therapeutic Strategies. Int J Mol Sci. 2018;19(8):2385. doi: 10.3390/ ijms19082385.

25. Fukaya T., Sugawara J., Yoshida H. et al. The role of macrophage colony stimulating factor in the peritoneal fluid in infertile patients with endometriosis. Tohoku J Exp Med. 1994;172(3):221-6. doi: 10.1620/tjem.172.221.

The study was a part of the research No.0120U101166 "The study of the pathogenetic role of the circadian molecular clock in the development of metabolic diseases and systemic inflammation and the development of treatment methods aimed at these processes" funded by the Ministry of Public Health of Ukraine. 


\section{ORCID and contributionship:}

Yuliia A. Orlova: 0000-0001-8839-1840 A-E

Antonina M. Hromova: 0000-0002-7396-7023 A,C,E,F

Igor P. Kaidashev: 0000-0002-4708-0859 E,I

Oksana A. Shlykova: 0000-0002-6764-2767 A,E

Olha V. Izmailova: 0000-0003-4770-3494 ${ }^{B}$

Vitaliiy B. Martynenko: 0000-0001-7465-0215 ${ }^{B}$

\section{Conflict of interest:}

The Authors declare no conflict of interest.

\section{CORRESPONDING AUTHOR}

\section{Yuliia A. Orlova}

Poltava State Medical University

23 Shevchenko St., 36000 Poltava, Ukraine

tel: +380502902161

e-mail:13vollmond13@gmail.com

Received: 17.04 .2021

Accepted: 29.07.2021

A - Work concept and design, B - Data collection and analysis, C - Responsibility for statistical analysis,

D-Writing the article, $\mathbf{E}$-Critical review, $\mathbf{F}-$ Final approval of the article 